
Bartın Üniversites
Eğitim Fakültesi Dergisi
Cilt 6, Sayı 2, s. 749-769, Haziran 2017 BARTIN - TÜRKIYE
Bartin University
Journal of Faculty of Education
Volume 6, Issue 2, p. 749-769, June 2017
BARTIN - TURKEY

Doi: 10.14686/buefad.315239

\title{
Öğretmen Adaylarının Net-Etik Davranışlarının Belirlenmesi
}

\author{
Mehmet KURT, Öğr.Gör.Dr., Ankara Üniversitesi Eğitim Bilimleri Fakültesi, mkurt@ankara.edu.tr \\ Necmettin TEKER, Yrd.Doç.Dr., Ankara Üniversitesi Eğitim Bilimleri Fakültesi, hatijoke@hotmail.com
}

Öz: Bu çalışma, internet ve sosyal ağların kullanımında öğretmen adaylarının net-etik davranış özelliklerini belirlemek amacıyla yapılmıştır. Araştırma tarama modelinde yürütülmüştür. Araştırmanın çalışma grubunu, Ankara Üniversitesi Eğitim Bilimleri Fakültesi'nde öğrenim gören 113'ü erkek 202'si kadın toplam 315 öğretmen adayı oluşturmaktadır. Öğretmen adaylarının yaşı, 18 ile 50 yaş aralığındadır, yaş ortalaması ise $24.5^{\prime}$ dir. Ölçekte yer alan maddeler 37 önermeden oluşmaktadır. Öğretmen adaylarının internet ve sosyal ağların kullanımında net-etik davranışlarını değerlendirmek için t-Testi, doğrusal regresyon ve varyans analizi kullanılarak test edilmiştir. Araştırmada elde edilen bulgular sonucunda; Erkekler kadınlara göre internette daha fazla vakit geçirmektedir. Internet kullanma becerisine göre erkekler kendilerini uzman derecesinde görürken kadınlar kendilerini orta derece görmektedirler. Yaş arttıkça kendini uzman olarak nitelendirenler azalmaktadır. Öğretmen adaylarının net-etik davranışları cinsiyete göre anlamlı bir farklılık göstermezken yaş, bölüm ve sınıf düzeylerine göre anlamlı farklılık göstermektedir. Kadın öğretmen adaylarının net-etik davranışları erkeklere göre daha yüksektir. Bölüm değişkenine göre yabancı diller programına kayıtlı olan öğretmen adaylarının net-etik davranışları; sırasıyla Fizik, BÖTE ve Türk Dili ve Edebiyatı programına kayıtlı adaylara göre daha yüksektir. Öğretmen adaylarının sınıf seviyesi yükseldikçe net-etik davranış puanlarının da arttığı görülmüştür. Diğer taraftan öğretmen adaylarının internet kullanma becerisinin, net-etik davranışlarının önemli bir yordayıcısı olduğu görülürken internet kullanma yılı ve internet kullanmak için bir gün içerisinde ortalama ayrılan sürenin anlamlı bir etkiye sahip olmadığı görülmektedir.

Anahtar Sözcükler: etik, net-etik, çevrim-içi iletişim, internet etiği, görgü kuralları

\section{Identifying Preservice Teachers' Netiquette Behaviors}

Abstract: The aim of this study was trying to identify net etiquette behaviors of preservice teachers. Survey model was used for the study. Participants of the study were 113 male, and 202 female in total 315 Faculty of Educational Sciences students at Ankara University. Participating preservice teachers' ages were between 18 and 50 years old and mean was 24.5 . There were 37 Likert scale items. To identify the preservice teachers' net etiquette behaviors while using internet and social networks independent group t-Test, linear regression and Variance Analysis were used. Based on the findings male participants were spending more time online than female. According to internet usage, male participants sow themselves at expert level while female sow themselves moderately. As age increases, the number of people who consider themselves experts decreases. While the netethical behaviors of the teacher candidates do not show any meaningful difference according to sex, they show significant differences according to age, department and class levels. The netiquette behavior of female teacher candidates was higher than that of male. Netiquette behaviors of teacher candidates registered to foreign language program according to department variable; were higher than candidates enrolled in Physics, BÖTE and Turkish Language and Literature programs respectively. The netiquette behavior scores also increased as the grade level of the teacher candidates increased. On the other hand, it seems that teacher candidates have a significant predictor of their net-ethical behavior, whereas the average number of years spent using the internet and using the internet does not seem to have any significant effect.

Key Words: ethics, netiquette, online communication, internet ethics, etiquette rules 


\section{GiRiş}

Günümüzde internet ve sosyal ağların çok hızlı bir şekilde gelişmesinin birey ve toplum üzerinde önemli değişimlere neden olduğu ve bu değişimlerin devam edeceği bir gerçektir. Internet ve sosyal ağların en önemli özelliği, bilgi ve iletişimin herkes için vazgeçilmez kaynak olarak görülmesinin yanı sıra etkileşimli yapısından kaynaklanmaktadır. İnternetin yaşamdaki bu önemi, onun sosyal, bireysel ve psikolojik etkilerini de tartışmaya açmaktadır. Bu noktada bir iletişim ortamı olarak internetin ve dolayısıyla interneti oluşturan araçların nasıl kullanılması gerektiği önemli bir sorun olarak ortaya çıkmaktadır (Gürcan, 2011).

Internet ve interneti oluşturan ortamların "araç" olarak çoğalması, çeşitlenmesi ve gelişmesi, alanda kullanıcı sayısının çok olması, kullanıc türevli içerik üretiminin hızlı ve çok olması kendine özgü bazı etik sorunlar oluşturduğundan söz etmek mümkün olabilir. Bu teknolojilere dayalı ortamlarda deneyimlenen etik sorunlar çok ve çeşitlilik göstermektedir. Özel yaşamın gizliliği ve bireysel özgürlükler, fikri mülkiyet, telif/patent hakları, dijital gözetim, veri madenciliği, nefret söylemi, kişisel verilerin güvenliğinin sağlanamaması, bilgiye erişim ve bilginin doğruluğu, sistem kalitesi, risk ve güvenirlik, üretilen içeriklerin olgunlaşmadan ve doğruluğunun teyit edilmeden yayılması, içeriğin ası kaynağının gösterilmemesi, yanıltıcı etiketleme ve başlıklandırma, haber ve ticari enformasyonun sınırlarının belirsizleşmesi, yeni medya ortamlarındaki yoğun reklam içeriği, bireyin yeni medya ortamında sadece tüketici olarak konumlandırıması (Akdeniz, 2016; Akın vd., 2010; Binark ve Bayraktutan, 2013, s.39; Bynum ve Rogerson, 2006; Heron vd., 2007; Kuzu, 2009; Khan, 2007; Namlu ve Odabaşı, 2007; TBD, 2011; Uysal, 2006) gibi sorunlar içermektedir. İternet ve interneti oluşturan ortamlarda etik sorumluluğun paydaşları endüstri gibi kurumsallaşmış yapılardan, bireysel kullanıcıya kadar uzanan çok taraflı bir görünüm arz etmektedir. Alanın çok yeni olduğu ve bu alanda hem profesyonellerin hem de "sıradan" yurttaşların rolü olduğu olgusudur. Bu bireysellik çoğu zaman etik anlamda daha bağımsız hareket eden, ya da bir başka deyişle herhangi bir kurumsal ilke ve kuralla sınırlandırılmayan bireyleri tanımlayan bir durumdur (Binark ve Bayraktutan, 2013, s.53). Başka bir anlatımla ortaya çıkan etik sorunların sorumluluk boyutunun geniş olmasından kaynaklanmaktadır.

Bilgisayar etiği, internet etiği, bilişim etiği, dijital etik gibi değişik isimlerle ifade edilen ve temelde insan ilişkilerinde yaşanan etik sorunların, meslekten mesleğe tümüyle değişmesinin söz konusu olmayacağı, birçok durumlarda benzerlikler ve kesişmeler taşıyacağı açıktır. Bu çalışmada, günümüzde kullanımı ihtiyaç haline gelen internet ve interneti oluşturan ortamlarda yaşanan etik sorunlar üzerinde durulacaktır. Türkçe karşıllı̆ı net-etik olarak kullanılan "Netiquette" kavramı, ağlar ve görgü kurallarını içeren iki sözcük birleştirilerek oluşturulmuştur (Preece, 2004). Bununla birlikte, Aggarwal (2014) net-etik teriminin internet ve görgü kuralları olmak üzere iki faktörü içerdiğini belirtmektedir.

Net-etik, "elektronik görgü kuralları" (Brusco, 2011) veya "Dijital iletişim etiği" (Aggarwal, 2014) olarak nitelendirilen "bilgisayar ağları veya sanal ortamlar vasıtasıyla iletişim kurarken uygun davranışsal görgü kuralları" anlamına gelmektedir (Yarmohammadian, Iravani ve Abzari, 2012). Başka bir deyişle net-etik, "çevrimiçi elektronik cihazlar veya etkinlikler kullanarak iletişim kurmanın doğru ve uygun yolu için kurallar" (Brusco, 2011) olarak tanımlanmaktadır. Aynı anlamda, Scheuermann ve Taylor (1997) ve Aranda (2007) net-etiği 
çevrimiçi görgü kuralları veya çevrimiçi iletişimi artırmak için izlenecek kurallar olarak görmektedir. Kısaca, net-etik: Ağ görgü kurallarının ya da internet görgü kurallarının bir konuşma dalı olan tartışma dosyaları (Usenet) ve posta listelerinden bloglara ve forumlara kadar değişen ağlar üzerinden etkileşimi kolaylaştıran bir toplumsal sözleşmeler dizisi olarak tanımlanabilir.

Internet ve sosyal ağlarda eş zamanlı ve eş zamanlı olmayan iletişim araçlarında sesli, görüntülü ve metin tabanlı etkileşimlere olanak sağlayan oldukça fazla ürün bulunmaktadır. Internet kullanıcıları dünyada hızlı bir şekilde arttığı için, internetin kendisi gibi bu gelişen normlar da değişen bir haldedir ve topluluktan topluluğa değişmektedir.

Tartışma dosyaları (Usenet) ve e-posta net-etiği hakkında en çok vurgulanan hususlar arasında basit elektronik imzaların kullanılması ve çoklu gönderme, çapraz ilanlar, konu dışı gönderimden kaçınma, bir tartışma dizesini ele geçirme, zincir iletilere yanıt vererek zincirin uzamasına neden olma, e-posta almayı beklemeyen kişilere ticari amaçla e-posta gönderme, gönderilen bir e-postayı sahibinden izin almadan genele açık ortamlara [örneğin tartışma grupları] gönderme, e-postada kullanılan referansları belirtmeme, mesajlaşma listesinden çıkartma gibi konular üzerinde yoğunlaşmaktadır (Altun, 2005, s.125-127; Uzun, 2011, s.311).

E-posta için yaygın kurallar çoğu kurum, medya ve topluluklarda sabitleşmiştir. Yüz yüze iletişimin birer parçası olan yüz ifadesi, bakış yönelimi, jestler, sözel olmayan ve sesli iletileri gönderme kapasitesi açısından internet ortamına göre farklılık gösterir. Illetişimde bulunanların, fiziksel varlıklarının görülmemesinden kaynaklanan oldukça düşük düzeyde bir sosyal varoluş içeren e-posta iletişiminde (Timisi, 2005, s.135), katılımcıların birbirlerini algılaması da yüz yüze iletişimdekine oranla daha zayıftır.

Eş zamanlı ve eş zamanlı olmayan sesli, görüntülü ve metin tabanlı iletişim araçlarında bir takım görsel destekler ve sembollerin kullanımına olanak sağlasa da net-etik kuralları; başkalarına karşı saygı, biçimsel özen ve içerikle ilgili özen konularında yoğunlaşmaktadır. Kimliğini saklayabileceğini umarak gerçek yaşamda benimsenmeyen davranışları sergilememek; saygılı olmak; duygusal yönden rahatsız edici iletilerin yayılmasına olanak vermemek; geçerli bir gerekçe olmadan kimliğini gizlememek; gereksiz yere büyük harfler ile yazışmaktan, sık sık özel simgeler kullanmaktan, esprili ya da alaycı anlatımlardan kaçınmak; gönderilen eklerin virus taşımamasına özen göstermek; başkalarının veri kaynaklarını, düşüncelerini ve yazııımlarını sahiplenmemek; kişilik haklarına ve özel yaşama saygı göstermek gibi kurallara uyulması istenmektedir (Altun, 2005; Uzun, 2011, s.312). Ayrıca, internet ortamının sağladığı olanakları her türlü sahtekarlık, yolsuzluk, dolandırıcılık ya da hırsızlık gibi kötü amaçla kullanmamak da gerekmektedir.

Dijital vatandaşlık, dijital teknolojiyi çevrimiçi kullanırken bir kişinin nasıl davranması gerektiği ve aynı zamanda çevrimiçi topluma katılma becerisi olarak tanımlanan bir terimdir. (ISTE, 2008; 2009;2016; Kocadağ, 2012) Dijital vatandaşlık; dijital erişim, dijital iletişim, dijital okuryazarlık, dijital etik, dijital ticaret, dijital hukuk, dijital hak ve sorumluluklar, dijital sağılı ve dijital güvenlik olmak üzere dokuz boyuttan oluşmaktadır. Dijital vatandaşık boyutları göz önüne alındığında, internet güvenliği ve net-etik ile ilgili olarak sıklıkla birlikte kullanılmaktadır. Dijital vatandaşlık kavramı 1998'in başlarından itibaren kullanılmaya başlandı ve yeni teknolojik 
ilerlemeler insanların birbirleri ile çevrimiçi etkileşim yöntemini ve frekansını değiştirdikçe açıklama konusunda öğrenciler, öğretmenler ve yöneticileri kapsayan çeşitli değişiklikler yapıldı. Artık dijital vatandaşılı derslerine eğitim sistemlerinde yer verilmektedir.

West'e göre (2010) resmi çevrimiçi kurslarında çevrimiçi araçlar ve uygulamalar kullanmakla mücadele eden birçok üniversite öğrenci topluluğu bulunmaktadır. West, öğrencilerin çoğunun Facebook, MySpace, Yahoo ve Google grupları gibi uygulamaları kullandığını belirtmektedir. Bununla birlikte üniversite öğrencileri, çevrimiçi öğrenme ortamlarında öğrenme için işbirliği araçlarını paylaşma aşamasında çevrimiçi etik kuralların uygulanmasına aşina olmadıkları ortaya çıkmıştır. Aynı anlamda, Deepa ve Ghatak (2013) çevrimiçi bireylerin birbirleri arasında gönderdikleri muazzam miktarda elektronik mesajın içeriğinde olduğu gibi tonunda da yanlış anlaşılabileceğini belirtmektedir. Bu durum olumsuz bir etkileşim sürecine neden olmaktadır. Bu nedenle, net-etik uygulamalarına duyulan ihtiyaç, çevrimiçi etkileşim sürecinin kalitesini artırmak için yaşamsal bir talep niteliğindedir.

Çevrimiçi ortamdaki iletişimin önündeki en büyük engel, duygusal ipuçlarının olmamasıdır. Yüz ipuçları, konuşmada iki insanın ruh halini ve karşılık gelen diksiyonunu belirler. Telefon konuşmaları sırasında, ses tonu kişinin duygularını bir diğer hatta iletir. Ancak sohbet odaları, anında mesajlaşma uygulamaları ve mesajlaşma ile bir kişinin sözlerinin tonunu veya duygu durumunu gösterecek herhangi bir sinyal bulunmamaktadır. Belki de en yaygın olan iki telafi edici davranış, ifadelerin ve kısaltmaların kullanılmasıdır. Ifadeler, yüz işaretleri ile ilgili ortak sembolleri göstermek için noktalama işaretleri kullanır. Örneğin, gülümseyen yüzün sembolünü yeniden oluşturmak için bir kişinin mutluluğunu veya memnuniyetini gösteren bir iki nokta üst üste ve parantez birleştirilir. Kahkahayı sembolize etmek için, "LOL" kısaltması geliştirildi. Bunlarla birlikte gülen bir yüz, üzgün yüz, ağlayan yüz, öfkeli yüz vb. yüz ifadeleri doğrultusunda Facebook ve diğer sosyal ağ mesajlaşma uygulaması üzerinden gönderebilen ve hislerimizi nasıl paylaştı̆̆ımız ve sohbetinize kişilik kazandırabileceğimiz harika bir yol olarak tanımlanan emojin çıkartmalarını içermektedir.

Daha önce yapılan tartışmalara göre, çevrimiçi etik kuralların oluşturulması için sürdürülebilir bir çaba gerektirdiğinden, net-etik davranışlarının öneminin fark edilmesi gereklidir fakat yeterli değildir. Çevrimiçi ortamlarda farklı seçenekler sunulması nedeniyle, Internet kullanıcıları net-etik kurallarını kullanmaya ve çevrimiçi etik kurallara sahipken diğer kullanıcıları desteklemeye çabalamalıdır. West'e (2010) göre, bireylerin etkileşimini etkileyen temel faktör, çevrimiçi iletişim kurallarını anlamaktır. Net-etik kurallarını kullanmak, kullanıııların daha güçlü çevrimiçi etkileşim topluluğu kurmalarına yardımcı olacaktır.

Bilgisayar ve sosyal ağ ortamlarının kendine özgü bir kültür, bireylere ve topluluğa özgü yeni ilişki türlerini ortaya çıkardığı bir gerçektir. Bilgisayar ve yeni sosyal medya ortamlarındaki eylemler ve sonuçlarının, etik ilkeler ve davranışlar bağlamında yeniden ele alınması zorunluluğunu da gündeme getirmektedir. Bu çalışmanın amacı, öğretmen adaylarının internet ve sosyal ağların kullanımında net-etik davranış özelliklerini belirlemektir. Bu amaç doğrultusunda, öğretmen adaylarının net-etik davranışları cinsiyet, yaş ve devam edilen programa göre anlamlamlı farklılık göstermekte midir? Öğretmen adaylarının internet kullanma düzey, süre ve sıklı̆ının net-etik davranışlarını anlamlı biçimde yordayabilmekte midir? sorularına yanıt aranmıştır. 


\section{YÖNTEM}

Bu başlık altında araştırmanın çalışma grubu tanımlanmış, veri toplama aracı, verilerin toplanması, analiz ve yapılan istatistiksel işlemler üzerinde durulmuştur. Araştırma, tarama modelinde olup mevcut durum ortaya konmaya çalışılmıştır.

\section{1. Çalışma Grubu}

Araştırmanın çalışma grubunu, Ankara Üniversitesi Eğitim Bilimleri Fakültesi Bilgisayar ve Öğretim Teknolojileri Eğitimi programında okuyan ( $n=165, \% 52.4$ ) ve pedagojik formasyon dersi alan (n=150, \%47.6) 202'si kadın (\%64.1), 113'ü erkek (\%35.9) toplam 315 öğretmen adayı oluşturmaktadır. Öğrencilerin yaş ortalaması 24.5 , yaş ranjları ise $18-50$ yaş arasındadır.

\subsection{Veri Toplama Aracı}

Veri toplama aracı olarak araştırmacılar tarafından geliştirilen ölçek kullanılmıştır. Ölçek formu kişisel bilgiler yanı sıra 37 önermeden oluşmaktadır. Öğretmen adaylarının netetik davranışları öz bildirime dayalı beşli likert tipi dereceleme ölçeği ile toplanan bilgilere dayanılarak belirlenmeye çalışılmıştır. Bu sorulardan elde edilen veriler, ölçeğin aralıklarının eşit olduğu kabulünden hareketle ve (1) "hiçbir zaman" dan (5) “her zaman" a doğru puan verilerek çözümlenmiştir. Ölçekten elde edilebilecek en yüksek puan 187, en düşük puan ise 37'dir. Yapılan analizler sonucunda net-etik davranışları ölçeğinin dört alt boyutu bulunmaktadır: E-Posta Kullanımı (15 madde), Mesaj Paylaşımı (10 madde), İçerik Üretimi (6 madde) ve Profil Kullanımından (6 madde) oluşmaktadır. Her bir faktörün açıklanan varyansa katkıları incelendiğinde birinci faktörün \% 16.858, ikinci faktörün \% 11.925, üçüncü faktörün \% 8.659 ve dördüncü faktörün ise \% 6.864 olarak bulunmuştur. Belirlenen bu dört faktörün toplam varyansa yaptıkları katkı ise $\% 44.306$ 'dır. Çok faktörlü desenlerde, özellikle sosyal bilimlerde ölçek geliştirmede, açıklanan varyansın \% 40 ile \% 60 arasında olması yeterli olarak kabul edilmektedir (Büyüköztürk, 2010; Çokluk, Şekercioğlu ve Büyüköztürk, 2012; Kalaycı, 2005; Şencan, 2005; Tavşancıl, 2005). Ölçeğin Cronbach's Alpha kullanılarak hesaplanan güvenirlik katsayısı 0.865 'tir. Bilindiği üzere, bu değerin .80 'nin üzerinde olması ölçek güvenirliğin yüksek olduğunu göstermektedir (Field, 2005). Ölçeğin alt boyutların güvenirlik katsayıları ise birinci faktör için $\alpha=0.897$, ikinci faktör için $\alpha=0.837$, üçüncü faktör için $\alpha=0.73$, dördüncü faktör için $\alpha=0.642$ olarak bulunmuştur. Madde güvenilirliği için ek kanıt üretmek amacıyla Guttman İki Yarı Test korelasyonu katsayıları da güvenilirlik ölçüsü olarak analiz sonuçlarında yer verilmektedir (Kalaycı, 2010). Yapılan bu analiz sonucunda faktörlere ait $0.850,0.816,0.659$ ve 0.532 olan güvenirlik katsayıları ölçek güvenilirliğinin iyi olduğunu göstermektedir.

\subsection{Verilerin Toplanması ve Analizi}

Araştırmada veri toplama süreci, araştırmacılar tarafından 2014-2015 öğretim yılı bahar döneminde, öğrencilere araştırmanın amacının özetlendiği birer yönergeyle bire bir uygulanmıştır. Araştırma, gönüllü katılımı esas alınarak gerçekleştirilmiştir ve araştırma süresince katılımcılardan gelen sorular cevaplanmıştır.

Verilerin istatistiksel analizleri için SPSS 17 paket programı kullanılmıştır. Araştırmanın amacı doğrultusunda veriler öğretmen adaylarının toplam puanı hesaplanarak yaş ve program 
türüne göre farklılık gösterip göstermediği tek yönlü varyans analizi (ANOVA) kullanılarak test edilmiştir. Varyans probleminin olduğu durumlarda $(p<.05)$ Field $(2000)$ tarafından önerilen Tamhane metodu kullanılmıştır. Varyans probleminin olmadığı durumlarda ise ( $p>.05)$ Huck (2000) tarafından önerilen Scheffe metodu kullanılmıştır. Öğretmen adaylarının cinsiyet değişkenine göre net-etik davranışlarının farklılık gösterip göstermediği ise ilişkisiz t-Testi kullanılarak test edilmiştir. Ayrıca bağımlı değişken üzerinde etkisi test edilen bağımsız değişkenin her bir alt düzeyinde dağılımın normal olup olmadığı One-Sample Kolmogrov Smirnova ile test edilmiştir. Öğretmen adaylarının internet kullanma düzeyi, yıl ve süresinin net-etik davranışlarının birer yordayıcısı olup olmadığını ortaya koymak için ise çoklu doğrusal regresyon analizi kullanılmıştır. Elde edilen verilerin analizinde $\alpha=0.05$ anlamlılık düzeyi esas alınmıştır. Ayrıca, $\alpha=0.01$ hata düzeyinde anlamlı çıkan sonuçlar çizelgelerde gösterilmiştir.

\section{BULGULAR}

Bu bölümde öğretmen adaylarının net-etik davranışları cinsiyet, yaş, program, internet kullanma sıklığı, yıl, beceri ve sürelerine yönelik bulgular sunulmuştur.

\section{1. Öğretmen Adaylarına İlişkin Demografik Bulgular}

Öğretmen adaylarından elde edilen veriler doğrultusunda demografik bulgular Tablo 1 'de verilmiştir. Adayların tamamına yakını ( $n=295, \% 93,7)$ her gün internet kullanırken çok azı ( $n=20 \%$ 6.3) haftada birkaç gün internet kullanmaktadır. Adayların \% 34,6'sı ( $n=109) 2$ ile 4 saat arasında internette vakit geçirirken bunu sırasıyla 4 saatin üzerinde kullananlar ( $n=77 \%$ 24.4), 1-2 saat kullananlar ( $n=69 \% 21.9$ ) ve 1 saatin altında ( $n=60 \% 19.0)$ internet kullananlar takip etmektedir.

Katılımcıların internet kullanma becerileri açısından \% 45.7'si ( $n=31$ ) ileri, \% 40.3'ü $(n=211)$ orta düzeyde internet kullanma becerisine sahip olduklarını belirtirken \%14.0'ü ise $(n=44)$ uzman düzeyinde internet kullanma becerisine sahip olduğunu belirtmektedir. Yine adayların yarıdan fazlası ( $n=183 \% 58.1) 5$ ile 9 yıldır internet kullandıklarını belirtirken yaklaşık üçte biri ise ( $n=111, \% 35.2) 10$ yıl ve üstünde internet kullandıklarını belirtmektedir. Grubun ancak çok az bir kısmı ( $n=\% 6.7) 4$ yıldan az bir süredir internet kullanmaktadır. Öğretmen adayların internete erişim yerleri açısından bakıldığında büyük bir çoğunluğu mobil teknolojiler ( $n=262, \%$ 83.2) üzerinden internete bağlanmayı tercih ederken dörtte üçü evden ( $n=237 \%$ 75.2), yarısına yakını okuldan ( $n=144, \% 45.7$ ), \% 19'u yurttan ve \% 10 ise internet kafeden internete erişebildiklerini belirtmektedir. 
Tablo 1.

Öğretmen Adaylarının Demografik Bulgularına Ilişkin Tanımlayıcı Istatistikler

\begin{tabular}{llrr}
\hline Değişkenler & & $\mathrm{N}$ & $\%$ \\
\hline İnternet Kullanma Sıklığı & Her gün & 295 & 93.7 \\
& Haftada Birkaç Gün & 20 & 6.3 \\
\hline \multirow{3}{*}{ Bir gün içerisinde internette } & 1 saatin altında & 60 & 19,0 \\
ortalama vakit geçirme süresi & 1-2 saat & 69 & 21,9 \\
& 2-4 saat & 109 & 34,6 \\
& 4 saatin üstünde & 77 & 24,4 \\
& Toplam & 315 & 100,0 \\
\hline \multirow{3}{*}{ Internet Kullanma Becerisi } & Orta & 127 & 40,3 \\
& Ileri & 144 & 45,7 \\
& Uzman & 44 & 14,0 \\
& Toplam & 315 & 100,0 \\
\hline \multirow{3}{*}{ Internet Kullanma Yılı } & 4 yıldan az & 21 & 6,7 \\
& $5-9$ yıl & 183 & 58,1 \\
& 10 yıl ve üstü & 111 & 35,2 \\
& Toplam & 315 & 100,0 \\
\hline \multirow{3}{*}{ Internete Erişim Yerleri } & Ev & 237 & 75.2 \\
& Yurt & 60 & 19.0 \\
& Okul & 144 & 45.7 \\
& İnternet Kafe & 33 & 10.5 \\
& Mobil & 262 & 83.2 \\
\hline
\end{tabular}

Öğretmen adaylarının cinsiyet değişkenine göre net-etik davranışlarının tamamı ve alt faktörlerden elde edilen puanlar arasında anlamlı bir farkın olup olmadığı Tablo 2'de t-testi ile sınanmıştır. Analiz sonuçlarına göre kadın ve erkek öğretmen adayları net-etik davranışları ölçeğin tamamından aldıkları puan ortalamaları arasında anlamlı bir farklılık $\left[\mathrm{t}_{(313)}=-1.676\right.$, p>.05] bulunmamıştır.

Tablo 2.

Öğretmen Adaylarııın Cinsiyete Değiş̧kenine Göre Net-etik Davranışlarına iliş̧kin t-Testi Sonuçları

\begin{tabular}{|c|c|c|c|c|c|c|c|}
\hline \multirow[t]{2}{*}{ Faktörler } & \multirow[t]{2}{*}{ Cinsiyet } & \multirow[t]{2}{*}{$\mathrm{N}$} & \multirow[t]{2}{*}{$\bar{x}$} & \multirow[t]{2}{*}{ SS } & \multicolumn{3}{|c|}{$t$-Testi } \\
\hline & & & & & $\mathrm{t}$ & Sd & $\mathrm{P}$ \\
\hline E-Posta & Kadın & 202 & 59,599 & 11,123 & -4.379 & 313 & $.000^{*}$ \\
\hline Kullanımı & Erkek & 113 & 54,265 & 8,855 & & & \\
\hline \multirow[t]{3}{*}{ Mesaj Paylaşımı } & Kadın & 202 & 20,723 & 6,443 & 3.828 & 313 & $.000^{*}$ \\
\hline & Erkek & 113 & 24,106 & 8,066 & & & \\
\hline & Kadın & 202 & 20,698 & 4,491 & -3.063 & 313 & $.002^{*}$ \\
\hline \multirow[t]{2}{*}{ İçerik Üretimi } & Erkek & 113 & 19,106 & 4,302 & & & \\
\hline & Kadın & 202 & 17,955 & 4,466 & .262 & 313 & .793 \\
\hline Profil Kullanımı & Erkek & 113 & 18,089 & 4,047 & & & \\
\hline \multirow[t]{2}{*}{ Toplam } & Kadın & 202 & 118,975 & 17,316 & -1.676 & 313 & .095 \\
\hline & Erkek & 113 & 115,566 & 17,312 & & & \\
\hline
\end{tabular}

${ }^{*} \mathrm{P}<.01$

Tablo 2 incelendiğinde net-etik davranış ölçeğinin alt boyutu olan e-posta kullanımı $\left[\mathrm{t}_{(313)}=-4.379, \mathrm{p}<.01\right]$, mesaj paylaşımı $\left[\mathrm{t}_{(313)}=3.828, \mathrm{p}<.01\right]$ ve içerik üretimi $\left[\mathrm{t}_{(313)}=-3.063\right.$, 
$p<.01]$ davranışlarından elde edilen puan ortalamaları ile cinsiyet arasında anlamlı bir farklılık görülürken cinsiyete göre profil kullanma davranış puan ortalamaları arasında anlamlı bir farklılık $\left[\mathrm{t}_{(313)}=.262, \mathrm{p}>\right.$.05]görülmemektedir. Başka bir anlatımla e-posta kullanımı ve içerik üretimi davranışlarında kadın öğretmen adaylarının lehine anlamlı bir görülürken mesaj paylaşımı davranışlarında ise erkek öğretmenlerin lehine anlamlı bir farklılık oluştuğu görülmektedir. Net-etik davranışları bütününde kadın ve erkek öğretmen adayları arasında anlamlı bir farklıık görülmezse bile kadın öğretmen adaylarının net-etik davranış puan ortalamaları erkek öğretmen adaylarının puan ortalamalarından fazla olduğu söylenebilir.

Öğretmen adaylarının net-etik davranışlarından aldıkları puanların yaş değişkenine göre değişip değişmediğini belirlemek için veriler üzerinde Tek Yönlü Varyans Analizi (ANOVA) uygulanmıştır. Sonuçlar Tablo 3'de verilmiştir. Tablo incelendiğinde öğretmen adaylarının netetik davranışlarının alt boyutları olan e-posta kullanımı $\left[\mathrm{F}_{(2-312)}=6.919, \mathrm{p}<.01\right]$ ve içerik üretimi davranışlarından $[\mathrm{F}(2-312)=5.839, p<.01]$ aldıkları puan ortalamaları yaş değişkenine göre anlamlı farklılık gösterirken mesaj paylaşımı $[\mathrm{F}(2-312)=.426$, $p>.05]$ ve profil kullanma davranışları $\left[F_{(2-312)}=.458, p>.05\right]$ puan ortalamaları yaş değişkenine göre anlamlı olmadığı görülmektedir. Öğretmen adayları yaş değişkenine göre net-etik davranışları ölçeğinin bütününden aldıkları puan ortalamaları arasında ise $\left[\mathrm{F}_{(2-312)}=5.230, p<.01\right]$ anlamlı farklıık göstermektedir.

Öğretmen adaylarının yaş değişkenine göre elde ettikleri puan ortalamaları arasında ortaya çıkan farkın hangi gruplardan kaynaklandığını belirlemek amacıyla verilere post hoch test olarak Scheffe modeli uygulanmıştır. Scheffe testi sonucunda; yaş değişkenine göre, 26 yaş ve üstü adayların e-posta kullanımı davranış puan ortalaması ( $\bar{x}=59.27)$ ile 21 yaş ve altında olan adayların e-posta kullanımı davranışları puan ortalaması $(\bar{x}=54.38)$ arasında 26 yaş ve üstü olan öğretmen adaylarının lehine anlamlı farklılıklar olduğu gözlenmiştir. Aynı zamanda 22-25 yaş arasındaki adayların e-posta kullanımı davranış puan ortalaması ( $\bar{x}=59.03)$ ile 21 yaş ve altında olan adayların e-posta kullanımı davranışları puan ortalaması ( $\bar{x}=54.38$ ) arasında 26 yaş ve üstünde olan öğretmen adaylarının lehine anlamlı farklılıklar olduğu gözlenmiştir.

Diğer taraftan 26 yaş ve üstü adayların içerik üretimi net-etik davranış puan ortalamaları ( $\bar{x}=20.77$ ) ile 21 yaş ve altında olan adayların içerik üretimi davranışları puan ortalaması $(\bar{x}=18.84)$ arasında 26 yaş ve üstü olan öğretmen adaylarının lehine anlamlı farklılıklar olduğu gözlenmiştir. Aynı zamanda 22-25 yaş arasındaki adayların içerik üretimi davranış puan ortalaması ( $\bar{x}=20.62$ ) ile 21 yaş ve altında olan adayların içerik üretimi davranışları puan ortalaması ( $\bar{x}=18.84$ ) arasında 22-25 yaş arasında olan öğretmen adaylarının lehine anlamlı farklıııklar olduğu gözlenmiştir.

Net-etik davranışlarının bütününde yaş değişkenine göre, 26 yaş ve üstü olan öğretmen adaylarının puan ortalaması ( $\bar{x}=119.63$ ) ile 21 yaş ve altı öğretmen adaylarının puan ortalaması ( $\bar{x}=113.04$ ) arasında 26 yaş ve üstü olan öğretmen adaylarının lehine anlamlı farklılık görülürken, 22-25 yaş arasındaki öğretmen adayların net-etik davranış puan ortalaması $(\bar{x}=119.98)$ ile 21 yaş ve altı öğretmen adaylarının puan ortalaması $(\bar{x}=113.04)$ arasında 2225 yaş arasındaki öğretmen adaylarının lehine anlamlı farklılık bulunmuştur. Bu bulgudan 
hareketle yaş arttıkça net-etik davranışlarının arttığı ve alt yaş gruplarında daha az görüldüğg̈ söylenebilir.

Tablo 3.

Öğretmen Adaylarının Yaş Değiş̧kenine Göre Net-etik Davranışlarına ilişkin Tek Yönlü Varyans Analizi Sonuçları

\begin{tabular}{|c|c|c|c|c|c|c|c|c|}
\hline Faktörler & Yaş & $\mathrm{N}$ & $\bar{x}$ & Ss & $\mathrm{Sd}^{*}$ & $F$ & $\mathrm{P}^{* *}$ & $\begin{array}{c}\text { Anlamlı Fark } \\
\text { (Scheffe) }\end{array}$ \\
\hline \multirow{3}{*}{$\begin{array}{l}\text { E-Posta } \\
\text { kullanımı }\end{array}$} & a) 21 yaş ve altı & 96 & 54,375 & 10,959 & \multirow{3}{*}{$(2,312)$} & \multirow{3}{*}{6.919} & \multirow{3}{*}{.001} & \multirow{3}{*}{$\begin{array}{l}a<b \\
a<c\end{array}$} \\
\hline & b) $22-25$ yaş & 117 & 59,026 & 9,229 & & & & \\
\hline & c) 26 yaş ve üstü & 102 & 59,265 & 11,302 & & & & \\
\hline \multirow{3}{*}{$\begin{array}{l}\text { Mesaj } \\
\text { Paylaşımı }\end{array}$} & a) 21 yaş ve altı & 96 & 22,167 & 7,035 & \multirow[b]{3}{*}{$(2,312)$} & \multirow[b]{3}{*}{.426} & \multirow[b]{3}{*}{.653} & \\
\hline & b) $22-25$ yaş & 117 & 22,222 & 8,158 & & & & \\
\hline & c) 26 yaş ve üstü & 102 & 21,392 & 6,289 & & & & \\
\hline \multirow{3}{*}{$\begin{array}{l}\text { Içerik } \\
\text { Üretimi }\end{array}$} & a) 21 yaş ve altı & 96 & 18,844 & 4,161 & & & & \\
\hline & b) $22-25$ yaş & 117 & 20,624 & 4,366 & \multirow[b]{2}{*}{$(2,312)$} & \multirow[b]{2}{*}{5.839} & \multirow[b]{2}{*}{.003} & $a<b$ \\
\hline & c) 26 yaş ve üstü & 102 & 20,765 & 4,695 & & & & $a<c$ \\
\hline \multirow{3}{*}{$\begin{array}{l}\text { Profil } \\
\text { Kullanımı }\end{array}$} & a) 21 yaş ve altı & 96 & 17,656 & 4,583 & \multirow{3}{*}{$(2,312)$} & \multirow{3}{*}{.458} & \multirow{3}{*}{.633} & \\
\hline & b) $22-25$ yaş & 117 & 18,111 & 4,238 & & & & \\
\hline & c) 26 yaş ve üstü & 102 & 18,206 & 4,161 & & & & \\
\hline \multirow{3}{*}{ Toplam } & a) 21 yaş ve altı & 96 & 113,042 & 17,832 & & & & \multirow{3}{*}{$a<b$} \\
\hline & b) $22-25$ yaş & 117 & 119,983 & 16,102 & \multirow[b]{2}{*}{$(2,312)$} & \multirow[b]{2}{*}{5.230} & \multirow[b]{2}{*}{.006} & \\
\hline & c) 26 yaş ve üstü & 102 & 119,628 & 17,610 & & & & \\
\hline
\end{tabular}

*Sd'de birinci rakam gruplararası, ikincisi gruplariçinin serbestlik derecesini gösterir $* * P<.01$

Öğretmen adaylarının net-etik davranışlarından aldıkları puanların öğrenim görülen bölüm değişkenine göre değişip değişmediğini belirlemek için veriler üzerinde Tek Yönlü Varyans Analizi (ANOVA) uygulanmıştır. Sonuçlar Tablo 4'te verilmiştir. Tablo 4 incelendiğinde öğretmen adayları net-etik davranışlarının alt boyutları olan e-posta kullanımı [F(3$311)=10.863, p<.01]$, mesaj paylaşımı $\left[F_{(3-311)}=6.157, p<.01\right]$ ve içerik üretimi davranışlarından aldıkları puan ortalamaları $\left[F_{(3-311)}=7.668, p<.01\right]$ öğrenim görülen bölüm değişkenine göre anlamlı farklılık gösterirken profil kullanma davranışları puan ortalamaları $\left[F_{(3-311)}=.652, p>.05\right]$ bölüm değişkenine göre anlamlı olmadığı görülmektedir. Öğretmen adaylarının öğrenim gördükleri bölüm değişkenine göre net-etik davranışları ölçeğinin 
bütününden aldıkları puan ortalamaları arasında ise $\left[\mathrm{F}_{(3-311)}=4.817, \mathrm{p}<.01\right]$ anlamlı farklılık göstermektedir.

Tablo 4.

Öğretmen Adaylarının Bölüm Değişkenine Göre Net-etik Davranışlarına Iliş̧kin Tek Yönlü Varyans Analizi Sonuçları

\begin{tabular}{|c|c|c|c|c|c|c|c|c|}
\hline Faktörler & Bölüm & $\mathrm{N}$ & $\bar{x}$ & SS & $S d^{*}$ & $\mathrm{~F}$ & $\mathrm{P}$ & $\begin{array}{c}\text { Anlamlı } \\
\text { Fark } \\
\text { (Tamhane) }\end{array}$ \\
\hline \multirow{4}{*}{$\begin{array}{l}\text { E-Posta } \\
\text { Kullanma }\end{array}$} & a) BÖTE & 165 & 55,82 & 10,227 & \multirow{4}{*}{$(3,311)$} & \multirow{4}{*}{10.863} & \multirow{4}{*}{$.000 * *$} & \multirow{4}{*}{$\begin{array}{l}d>a \\
d>c\end{array}$} \\
\hline & b) Türk Dili ve Edb. & 45 & 59,69 & 10,896 & & & & \\
\hline & c) Fizik & 47 & 54,70 & 11,794 & & & & \\
\hline & d) Yabancı Diller & 58 & 63,86 & 7,891 & & & & \\
\hline \multirow{4}{*}{$\begin{array}{l}\text { Mesaj } \\
\text { Paylaşımı }\end{array}$} & a) BÖTE & 165 & 23,37 & 8,172 & \multirow{4}{*}{$(3,311)$} & \multirow{4}{*}{6.157} & \multirow{4}{*}{$.000 * *$} & \\
\hline & b) Türk Dili ve Edb. & 45 & 18,80 & 3,888 & & & & \\
\hline & c) Fizik & 47 & 21,83 & 7,696 & & & & $a>b$ \\
\hline & d) Yabancı Diller & 58 & 20,38 & 4,580 & & & & $a>d$ \\
\hline \multirow{4}{*}{$\begin{array}{l}\text { Icçerik } \\
\text { Üretimi }\end{array}$} & a) BÖTE & 165 & 19,44 & 4,176 & \multirow{4}{*}{$(3,311)$} & \multirow{4}{*}{7.668} & \multirow{4}{*}{$.000 * *$} & \\
\hline & b) Türk Dili ve Edb. & 45 & 20,89 & 4,217 & & & & \\
\hline & c) Fizik & 47 & 19,11 & 5,313 & & & & $d>a$ \\
\hline & d) Yabancı Diller & 58 & 22,33 & 4,050 & & & & $d>c$ \\
\hline \multirow{4}{*}{$\begin{array}{l}\text { Profil } \\
\text { Kullanma }\end{array}$} & a) BÖTE & 165 & 17,98 & 4,369 & \multirow{4}{*}{$(3,311)$} & \multirow{4}{*}{.652} & \multirow{4}{*}{.582} & \multirow{4}{*}{--} \\
\hline & b) Türk Dili ve Edb. & 45 & 18,49 & 4,440 & & & & \\
\hline & c) Fizik & 47 & 17,32 & 4,864 & & & & \\
\hline & d) Yabancı Diller & 58 & 18,26 & 3,562 & & & & \\
\hline \multirow{4}{*}{ Toplam } & a) BÖTE & 165 & 116,60 & 17,460 & \multirow{4}{*}{$(3,311)$} & \multirow{4}{*}{4.817} & \multirow{4}{*}{$.003^{* *}$} & \multirow{4}{*}{$\begin{array}{l}d>a \\
d>c\end{array}$} \\
\hline & b) Türk Dili ve Edb. & 45 & 117,87 & 17,793 & & & & \\
\hline & c) Fizik & 47 & 112,96 & 20,045 & & & & \\
\hline & d) Yabancı Diller & 58 & 124,83 & 11,896 & & & & \\
\hline
\end{tabular}

*Sd'de birinci rakam gruplararası, ikincisi gruplariçinin serbestlik derecesini gösterir $* * P<.01$

Öğretmen adaylarının öğrenim görülen bölüm değişkenine göre elde ettikleri puan ortalamaları arasında ortaya çıkan farkın hangi gruplardan kaynaklandığını belirlemek amacıyla verilere post hoch test olarak Tamhane metodu uygulanmıştır. Yapılan test sonucunda; yabancı diller öğretmen adaylarının bölüm değişkenine göre, e-posta kullanımı davranış puan ortalaması ( $\bar{x}=63.27$ ) ile BÖTE bölümü öğretmen adayların e-posta kullanımı davranışları puan ortalaması ( $\bar{x}=55.82$ ) ve Fizik öğretmenleri e-posta kullanımı davranışları puan ortalaması ( $\bar{x}$ $=54.70$ ) arasında yabancı dil öğretmen adaylarının lehine anlamlı farklılıklar olduğu gözlenmiştir. 
Yine içerik üretimi ve net-etik davranışlarının bütününde bölüm değişkenine göre BÖTE bölümü ve Fizik öğretmenleri ile yabancı dil öğretmen adayları arasında yabancı dil öğretmen adaylarının lehine anlamlı olacak farklılıklar gözlenmiştir. BÖTE bölümü öğretmen adayların program değişkenine göre mesaj paylaşımı davranışları puan ortalaması $(\bar{x}=23.37)$ ile Türk Dili ve Edebiyatı bölümü öğretmen adayların mesaj kullanımı davranışları puan ortalaması ( $\bar{x}$ $=18.80$ ) ve yabancı diller öğretmen adaylarının mesaj paylaşımı davranışları puan ortalaması ( $\bar{X}=20.38$ ) arasında BÖTE bölümü öğretmen adayların lehine anlamlı farklılık bulunmuştur.

Öğretmen adaylarının net-etik davranışlarından aldıkları puanların sınıf değişkenine göre değişip değişmediğini belirlemek için veriler üzerinde Tek Yönlü Varyans Analizi (ANOVA) uygulanmıştır. Sonuçlar Tablo 5'te verilmiştir. Sertifika grubunda olan öğretmen adaylarının tamamı mezunlardan oluştuğu için herhangi bir sınıfa dahil edilmemiştir. Tablo 5 incelendiğinde öğretmen adayları net-etik davranışlarının alt boyutları olan e-posta kullanımı $\left[F_{(4-310)}=9.159, p<.01\right]$, mesaj paylaşımı $\left[F_{(4-310)}=7.962, p<.01\right]$ ve içerik üretimi davranışlarından aldıkları puan ortalamaları $\left[F_{(4-310)}=4.686, p<.01\right]$ öğrenim görülen sınıf değişkenine göre anlamlı farklılık gösterirken profil kullanma davranışları puan ortalamaları $\left[F_{(4-310)}=.527, p>.05\right]$ anlamlı olmadığı görülmektedir. Öğretmen adaylarının öğrenim gördükleri sınıf değişkenine göre net-etik davranışları ölçeğinin bütününden aldıkları puan ortalamaları arasında ise $\left[F_{(4-310)}=4.183, p<.01\right]$ anlamlı farklılık göstermektedir.

Öğretmen adaylarının öğrenim görülen sınıf değişkenine göre elde ettikleri puan ortalamaları arasında ortaya çıkan farkın hangi gruplardan kaynaklandığını belirlemek amacıyla verilere post hoch test olarak Scheffe ve Tamhane metodu uygulanmıştır. Yapılan test sonucunda; BÖTE bölümü birinci sınıfa devam eden öğretmen adayların e-posta kullanımı davranışları puan ortalaması ( $\bar{x}=49.60)$ ile üçüncü sınıfa devam edenlerin puan ortalaması $(\bar{x}$ $=60.23)$, dördüncü sınıfa devam edenlerin puan ortalaması $(\bar{x}=57.07)$ ve mezun olan öğretmen adayları puan ortalaması $(\bar{x}=59.64)$ arasında birinci sınıfa devam eden öğretmen adaylarının aleyhine anlamlı farklıııklar olduğu gözlenmiştir. İkinci sınıfların mesaj paylaşımı davranışları puan ortalaması $(\bar{x}=25.62)$ ile üçüncü sınıfların puan ortalaması $(\bar{x}=21.06)$ arasında ve yine ikinci sınıfların puan ortalaması ile mezunlar puan ortalaması $(\bar{x}=20.36$ ) arasında ikinci sınıfların lehine anlamlı farklılık bulunmuştur. İçerik üretimi davranışlarında ise birinci sınıfa devam eden öğretmen adayların puan ortalaması ( $\bar{x}=17.63$ ) ile üçüncü sınıfa devam edenlerin puan ortalaması $(\bar{x}=20.48$ ) arasında ve birinci sınıfların puan ortalaması ile mezunların puan ortalaması ( $\bar{x}=20.89$ ) arasında birinci sınıfların aleyhine anlamlı farklılık bulunmuştur. Sınıf değişkenine göre profil kullanma davranışları açısından öğretmen adayları arasında anlamlı farklılık bulunmamıştır. 
Tablo 5.

Öğretmen Adaylarının Sınıf Değişkenine Göre Net-etik Davranışlarına Iilişkin Tek Yönlü Varyans Analizi Sonuçları

\begin{tabular}{|c|c|c|c|c|c|c|c|c|}
\hline Faktörler & Sinıf & $\mathrm{N}$ & $\bar{x}$ & SS & SD* & $\mathrm{F}$ & $P$ & $\begin{array}{c}\text { Anlamlı } \\
\text { Fark }\end{array}$ \\
\hline \multirow{5}{*}{$\begin{array}{l}\text { E-Posta } \\
\text { Kullanma }\end{array}$} & a) 1.sınıf & 35 & 49,60 & 12,617 & \multirow{5}{*}{$(4,310)$} & \multirow{5}{*}{9.159} & \multirow{5}{*}{$.000 * *$} & (Scheffe) \\
\hline & b) $2 . \sin I f$ & 34 & 53,85 & 8,254 & & & & $a<c$ \\
\hline & c) $3 . \sin I f$ & 52 & 60,23 & 8,092 & & & & $a<d$ \\
\hline & d) $4 . \sin$ If & 44 & 57,07 & 9,133 & & & & $a<e$ \\
\hline & e) mezun & 150 & 59,74 & 10,791 & & & & \\
\hline \multirow{5}{*}{$\begin{array}{l}\text { Mesaj } \\
\text { Paylaşımı }\end{array}$} & a) 1.sınıf & 35 & 21,57 & 6,779 & \multirow{5}{*}{$(4,310)$} & \multirow{5}{*}{7.962} & \multirow{5}{*}{$.000 * *$} & (Tamhane) \\
\hline & b) $2 . \sin ı f$ & 34 & 25,62 & 7,037 & & & & \\
\hline & c) $3 . \sin$ If & 52 & 21,06 & 7,296 & & & & $b>c$ \\
\hline & d) 4.sınıf & 44 & 25,80 & 9,906 & & & & $b>e$ \\
\hline & e) mezun & 150 & 20,36 & 5,674 & & & & \\
\hline \multirow{5}{*}{$\begin{array}{l}\text { Içerik } \\
\text { Üretimi }\end{array}$} & a) $1 . \sin I f$ & 35 & 17,63 & 4,989 & \multirow{5}{*}{$(4,310)$} & \multirow{5}{*}{4.686} & \multirow{5}{*}{$.001^{* *}$} & (Tamhane) \\
\hline & b) $2 . \sin ı f$ & 34 & 18,94 & 3,246 & & & & \\
\hline & c) $3 . \sin$ If & 52 & 20,48 & 3,506 & & & & $a<c$ \\
\hline & d) $4 . \sin ı f$ & 44 & 20,02 & 4,433 & & & & $a<e$ \\
\hline & e) mezun & 150 & 20,89 & 4,695 & & & & \\
\hline \multirow{5}{*}{$\begin{array}{l}\text { Profil } \\
\text { Kullanma }\end{array}$} & a) 1.sınıf & 35 & 18,09 & 5,622 & \multirow{5}{*}{$(4,310)$} & \multirow{5}{*}{.527} & \multirow{5}{*}{.716} & \multirow{5}{*}{--} \\
\hline & b) $2 . \sin I f$ & 34 & 18,85 & 3,831 & & & & \\
\hline & c) $3 . \sin$ If & 52 & 17,71 & 3,648 & & & & \\
\hline & d) $4 . \sin ı f$ & 44 & 17,52 & 4,454 & & & & \\
\hline & e) mezun & 150 & 18,03 & 4,268 & & & & \\
\hline \multirow{5}{*}{ Toplam } & a) 1.sınıf & 35 & 106,89 & 23,138 & \multirow{5}{*}{$(4,310)$} & \multirow{5}{*}{4.183} & \multirow{5}{*}{$.003^{* *}$} & (Scheffe) \\
\hline & b) $2 . \sin ı f$ & 34 & 117,26 & 13,574 & & & & \\
\hline & c) 3.sinıf & 52 & 119,48 & 13,336 & & & & $a<c$ \\
\hline & d) 4.sınıf & 44 & 120,41 & 16,880 & & & & $a<d$ \\
\hline & e) mezun & 150 & 119,02 & 17,227 & & & & $a<e$ \\
\hline
\end{tabular}

*Sd'de birinci rakam gruplararası, ikincisi gruplariçinin serbestlik derecesini gösterir $* * P<.01$

Net-etik davranışlarının bütününde birinci sınıfa devam eden öğretmen adaylarının puan ortalaması ( $\bar{x}=106.89)$ ile üçüncü sınıf $(\bar{x}=119.48)$, dördüncü sınıf $(\bar{x}=120.41)$ ve mezun öğretmen adaylarının puan ortalamaları $(\bar{x}=119.02)$ arasında birinci sınıfların aleyhine 
anlamlı farklııı bulunmuştur. Başka bir anlatımla birinci sınıfa devam eden BÖTE bölümü öğretmen adaylarının net-etik davranışları üçüncü sınıf ve dördüncü sınıfa giden BÖTE bölümü öğretmen adaylarının net-etik davranışlarına oranla daha az görülmektedir. Birinci sınıfa devam eden BÖTE bölümü öğretmen adayları ile öğretmenlik sertifika programına devam eden mezun konumundaki öğretmen adayları arasında da aynı durum görülmektedir. Burada dikkati çeken önemli bir diğer husus sınıf seviyesi yükseldikçe öğretmen adaylarının net-etik davranışlarında bir artma görüldüğü söylenebilir. Öğretmenlik sertifika programına devam eden mezun konumundaki öğretmen adaylarının net-etik davranış oranları BÖTE bölümü dördüncü sınıf öğretmen adaylarının net-etik davranışlarının gerisine düşse de birinci ve ikinci sınıfa giden öğretmen adaylarının net-etik davranışlarına oranla daha fazladır.

Öğretmen adaylarının internet kullanma becerisi, internet kullanma yılı ve bir gün içerisinde internet kullanmak için ayrılan süre değişkenine göre net-etik davranışlarının yordanmasına ilişkin regresyon analizi Tablo 6 'da verilmiştir.

Tablo 6.

Net-etik Davranışlarının Yordanmasına ilişkin Çoklu Regresyon Analizi Sonuçları

\begin{tabular}{lrrrrrrr}
\hline Değişken & B & Standart Hata & $\beta$ & $T$ & $\mathrm{P}$ & ikili $r$ & Kısmi $r$ \\
\hline Sabit & 97.869 & 5.309 & -- & 18.435 & .000 & & \\
Beceri & 4.753 & 1.464 & .189 & 3.246 & .003 & $.205^{* *}$ & $.181^{* *}$ \\
Kullanılan Yıl & 3.253 & 1.680 & .109 & 1.936 & .054 & $.140^{* *}$ & .109 \\
Ayrılan Süre & -.272 & 1.525 & -.010 & .133 & .859 & .059 & -.010 \\
\hline $\mathrm{R}=.231$ & $\mathrm{R}=.053$ & & & & & & \\
$\mathrm{~F}_{(3,311)}=5.829$ & $\mathrm{P}=.001$ & & & & & & \\
\hline
\end{tabular}

Yordayıcı değişkenlerle bağımlı değişken arasındaki ikili ve kısmi korelasyonlar incelendiğinde internet kullanma becerisi ile net-etik davranışlar arasında pozitif, anlamlı ve düşük düzeyde bir ilişkinin ( $r=0.21)$ olduğu, ancak diğer değişkenler kontrol edildiğinde iki değişken arasındaki korelasyonun $r=0.18$ olarak hesaplandığı görülmektedir. İnternet kullanma yılı ile net-etik davranışlar arasındaki pozitif, anlamlı ve düşük düzeyde $(r=0.14)$ bir ilişki vardır. Ancak diğer iki değişken kontrol edildiğinde, bu korelasyonun $r=0.11$ olarak hesaplandığı görülmektedir. Öğretmen adaylarının bir gün içerisinde internet kullanmaya ayırdıkları süre puanları ile net-etik davranışları arasında hesaplanan doğrusal ve sıfır düzeyinde $(r=0.06)$, ikili korelasyonun ise diğer iki değişken kontrol edildiğinde doğrusal ve sıfır düzeyinde ( $r=-0.010)$ ilişki olduğu görülmektedir.

Internet kullanma becerisi, kullanılan yıl ve internet kullanmak için bir gün içinde ayrılan süre değişkenleri ile birlikte, öğretmen adaylarının net-etik davranış puanları ile düşük düzeyde ve anlamlı bir ilişki vermektedir. $R=0.231, R^{2}=0.053, p<0.01$. adı geçen üç değişken birlikte, net-etik davranışlarındaki toplam varyansın \%5.3'ünü açıklamaktadır. Geriye kalan \%94.7'lik kısım ise hata terimi vasıtasıyla modele dahil edilmeyen değişkenler tarafından açıklanmaktadır. 
Tablodan görülebileceği gibi sabit terim 97.869 olarak bulunmuştur. Bunun anlamı internet kullanma becerisi, internet kullanma yılı ve internet kullanmak için bir gün içerisinde ayrılan süre puanları sıfır bile olsa öğretmen adayları 97.869 birimlik bir puan elde etmektedir. Standardize edilmiş regresyon katsayısına $(\beta)$ göre, yordayıcı değişkenlerin net-etik davranışları üzerindeki göreli önem sırası, internet kullanma becerisi, internet kullanma yılı ve internet kullanmak için bir gün içerisinde ayrılan süredir. Regresyon katsayılarının anlamlılığına ilişkin ttesti sonuçları incelendiğinde ise, sadece internet kullanma becerisi değişkeninin net-etik davranışları üzerinde önemli (anlamlı) bir yordayıcı olduğu görülmektedir. İnternet kullanma yılı ve internet kullanmak için bir gün içerisinde ayrılan süre değişkenleri önemli bir etkiye sahip değildir.
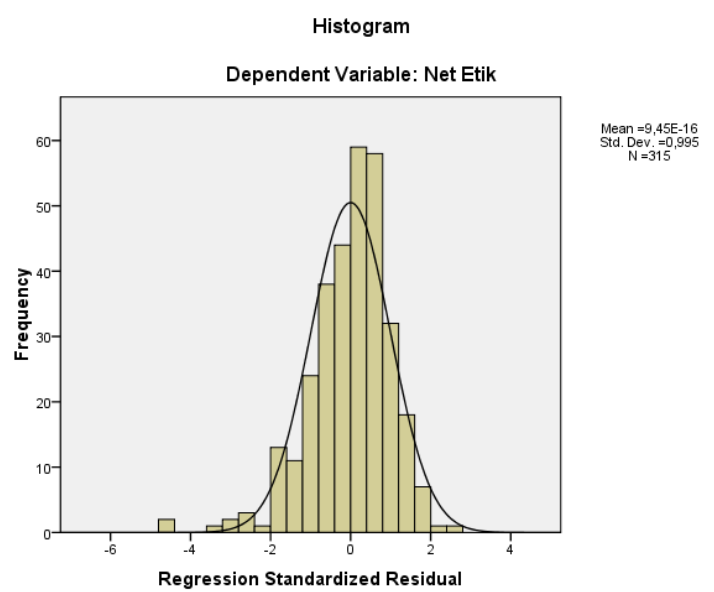

Normal P-P Plot of Regression Standardized

Residual

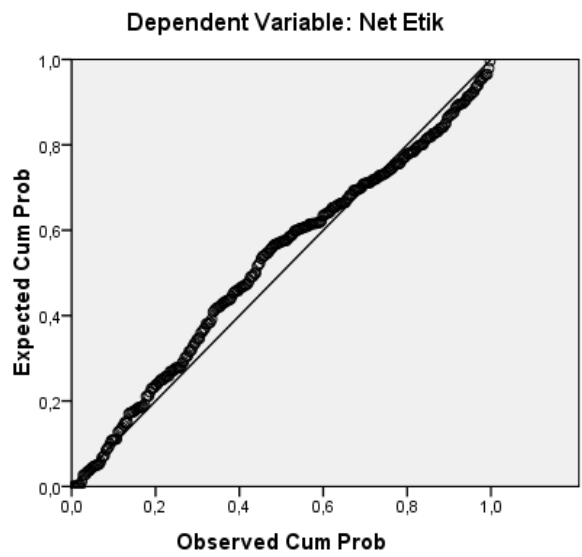

Şekil 1. Normallik ve doğrusallık varsayımına ilişkin grafikler

Şekil 1'de verilen grafikler incelendiğinde, standardize edilmiş artık değerler ile standardize edilmiş yordanan değerler için oluşturulan saçılma diyagramının doğrusal bir ilişkiyi tanımladığı, noktaların bir eksen etrafında toplanma eğiliminde olduğu görülmektedir. Standardize edilmiş yordanan değerler için oluşturulan histogram ve normal dağılım eğrisi de normal dağılım göstermektedir. Başka bir ifadeyle yordayıcı değişkenlerle bağımlı değişken arasındaki ilişkinin doğrusal ve puanların normal dağılım gösterdiği ya da normallik varsayımının karşılandığı söylenebilir. 

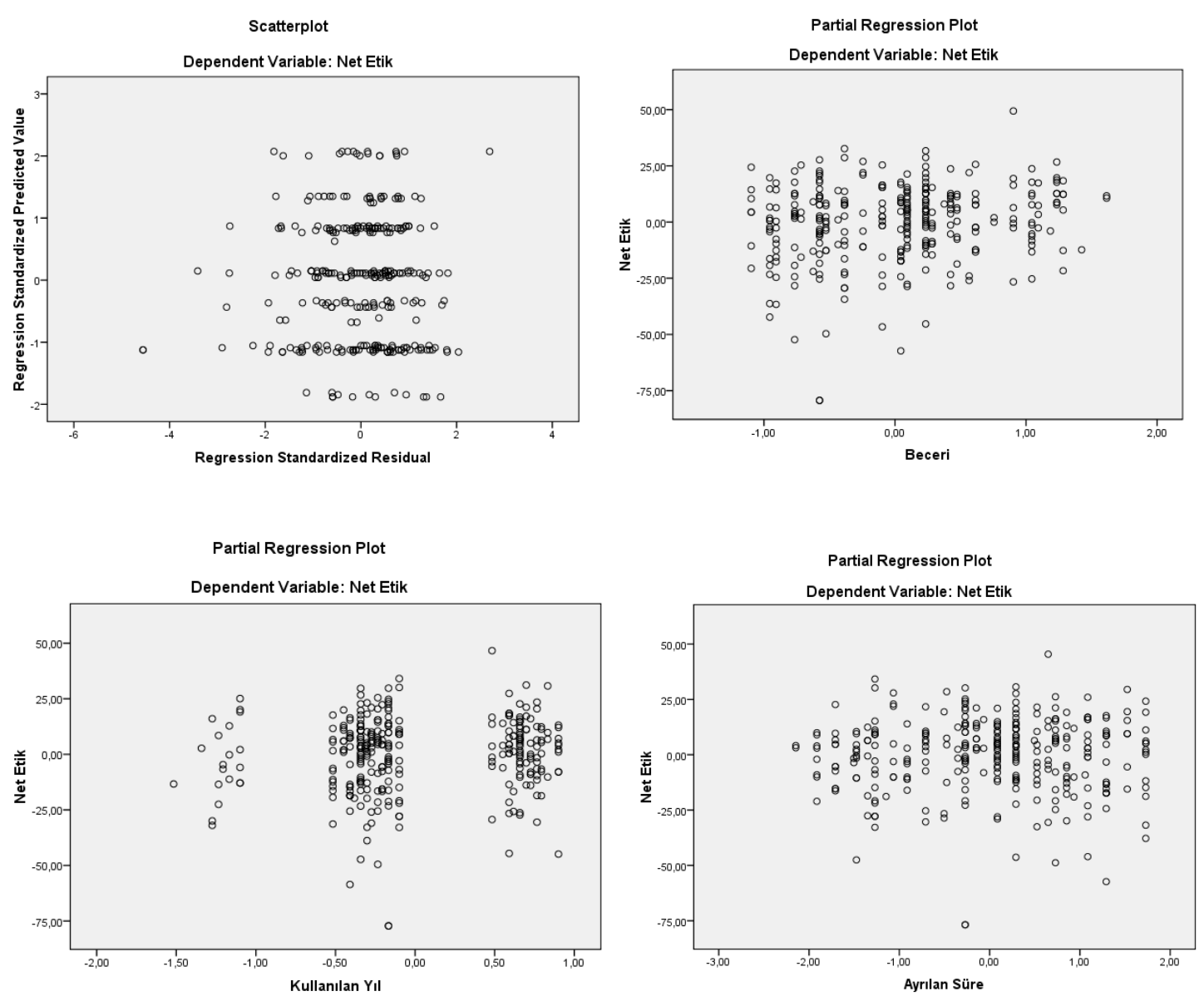

Şekil 2. Çoklu regresyon analizine ilişkin grafikler

Öte yandan, Şekil 2'de yordayıcı değişkenlerin bağımlı değişkenlerle verdikleri kısmı ilişkileri temel alan saçılma diyagramlarından internet kullanma becerisi ile net-etik davranışlar arasında doğrusal ve pozitif; net-etik ile internet kullanma yılı ve bir gün boyunca internette kalma süresi arasında sıfıra yakın bir ilişki olduğu görülmektedir.

\section{TARTIŞMA, SONUÇ VE ÖNERILER}

Öğretmen adaylarının net-etik davranışlarından aldıkları puanların cinsiyete göre farklılaşıp farklılaşmadığına ilişkin elde edilen bulgular değerlendirildiğinde anlamlı fark bulunmamıştır. Ancak net-etik davranışların alt boyutları olan e posta kullanımı, mesaj paylaşımı ve içerik üretiminden aldıkları puanlar açısından cinsiyete göre anlamlı farklılıklar bulunurken profil kullanma davranışları puan ortalamaları arasında anlamlı fark bulunmamıştır. Kadın öğretmen adaylarının e-posta kullanımı ve içerik üretimi davranış puanları erkek adaylardan fazlayken profil kullanma puanları ise erkek adayların puanlarından az olduğu çıkmıştır. Arouri ve Hamaidi (2017) tarafından TTU-Ürdün Eğitim Bilimleri Fakültesi özel eğitim ve sınıf öğretmeni 245 öğrenci üzerinde yapılan çalışmada cinsiyete göre anlamlı farklılık olmadığı rapor edilmektedir. Sonuç olarak bu çalışmada da belirli net-etik kuralları hakkında sınırlı farkındalık oluştuğu bulunmuştur. Bu değişkenle ilgili cinsiyet araştırmalarının farklı 
örneklemlerde sürdürülmesinin net-etik davranışları üzerindeki etkisinin aydınlatılması açısından yararlı olacağı düşünülmektedir.

Öğretmen adaylarının yaş değişkenine göre farklılaşıp farklılaşmadığına ilişkin elde edilen bulgular net-etik davranışlarının bütünü göz önünde bulundurulduğunda anlamlı fark bulunmuştur. 26 yaş ve üzerindeki öğretmen adayları ile 22-25 yaş arasındaki öğretmen adayları 21 yaş ve altındakilere göre net-etik davranışları daha yüksektir. Net-etik davranışların alt boyutları olan e posta kullanımı ve içerik üretiminden aldıkları puanlar açısından yaş değişkenine göre anlamlı farklılıklar bulunurken mesaj paylaşımı ve profil kullanma davranışları puan ortalamaları arasında anlamlı fark bulunmamıştır. Bu bulgudan hareketle öğretmen adaylarının yaş seviyesi arttıkça net-etik davranışlarını daha fazla gösterdiği söylenebilir.

Öğretmen adaylarının net-etik davranışlarının program türlerine göre farklılaşıp farklılaşmadığına ilişkin elde edilen bulgular göz önünde bulundurulduğunda anlamlı farklık bulunmuştur. Yabancı diller programında olan öğretmen adayları, net-etik davranışlarını sırasıyla Fizik, BÖTE ve Türk Dili ve Edebiyatı programındaki adaylara göre daha fazla göstermektedir. Program türüne göre net-etik davranışlarının alt boyutlarında ise e-posta kullanımı ve içerik üretimi davranışları puan ortalamaları arasında yabancı dil öğretmen adayları lehine anlamlı fark bulunurken mesaj paylaşımı davranışlarında ise BÖTE programındaki öğretmen adaylarının lehine anlamlı fark bulunmuştur. Program türüne göre profil kullanımında ise öğretmen adaylarının puan ortalamaları arasında anlamlı fark bulunmamıştır. Genel olarak bakıldığında net-etik davranışların gösterilmesinde yabancı diller ve Türk dili ve Edebiyatı programındaki öğretmen adaylarının puanları daha fazla çıkmaktadır. Bu farklılığın etkili iletişim, yazma ve kendini ifade etme konusunda dil gruplarındaki adayların programa özgü aldığı derslerden kaynaklandığı düşünülmektedir. Farshad ve Marandi'nin (2014) yabancı dil olarak 75 İngilizce (EFL) öğrenenler ile 53 yerli İngilizce öğrenen meslektaşlarının net-etik kurallarına aşina olup olmadıklarını ve net-etik kurallarını yararlı olarak algıladıklarını keşfetmek için karşılaştırmalı bir araştırma yapmıştır. Çalışmanın sonuçlarına göre, EFL öğrencilerinin, net-etik kurallarına yeterince aşina olmadığını ve net-etik kurallarının yerli ingilizce öğrencileri ile karşılaştırıldığında kullanışııı̆̆ını ve gerekliliğini fark etmediklerini belirtmektedir. Bu çalışmada elde edilen sonucun sadece dil grupları arasında yapılmış olmasına rağmen farklı program türleri arasında uygulandığında dil grubunda olan adayların lehine bir durum çıkacağı düşünülmektedir. Sonuç olarak bu değişkenle ilgili olarak fen, teknik ve teknoloji tabanlı programlarla dil, sosyal ve beşeri bilimler programlarını yansıtacak farklı araştırma örneklemleri üzerinde sürdürülmesinin yararlı olacağı düşünülmektedir.

Öğretmen adaylarının internet kullanma becerisi, internet kullanma yılı ve bir gün içerisinde internet kullanmak için ortalama ayırdıkları sürenin net-etik davranışlarının yordanmasına ilişkin yapılan regresyon analizinde internet kullanma becerisinin varyansa katkısı bakımından net-etik davranışlarının önemli bir yordayıcısı olduğu görülürken internet kullanma yılı ve internet kullanmak için bir gün içerisinde ortalama ayrılan sürenin varyansa katkısı bakımından bu iki değişkenin anlamlı bir etkiye sahip olmadığı görülmektedir. Regresyon katsayısının işaretine bakıldığında internet kullanma becerisi ile net-etik davranışları arasındaki ilişkinin pozitif olduğu görülmektedir. 
Bilgisayar ve yeni sosyal medya ortamlarında ister sıradan bir kullanıcı isterse de meslek profesyoneli olsun etik davranma ve üretmenin kuralları çevrimdışı dünyada var olan etik kurallardan ve ilkelerden bağımsız ve farklı değildir. Örneğin kaynak göstermeden içerik kullanmak, nefret söylemi, aşırı ticari içerik vb. sorunlar çevrimdışı dünyada var olan ve çevrimiçi dünyada da yeni sosyal medya ortam ve araçlarına özgü özellikler nedeniyle etki alanı genişleyen sorunlardır (Binark ve Bayraktutan, 2013). Bireysel kullanıcıların var olduğu alanlar ve kullandığı araçların çeşitliliği göz önüne alındığında her bir araç ve ortam için ilke belirlemek anlamlı olmayacaktır. Ancak bu durum, alana ilişkin etik sorunların değerlendirilmesi, temel prensip ve öneri geliştirilmesine engel değildir.

$\mathrm{Bu}$ araştırmanın çalışma grubunu oluşturan katılımcıların yalnızca öğretmen adaylarından oluşması bir sınırlılık olarak değerlendirilirse, ileride farklı alanlardan öğrenme deneyimlerine sahip öğrencilerin net-etik davranışlarının yeniden sorgulanmasının yararlı olacağı düşünülmektedir. Ayrıca, yine ileride gerçekleştirilecek çalışmalarla ortaokul ve lise düzeyindeki öğrencilerin net-etik davranışlarıyla öğretmenlerin gösterdikleri davranışlar karşılaştırmalı olarak araştırılabilir.

\section{KAYNAKLAR}

Aggarwal, A. K. (2014). Netiquette in e-learning. Proceedings for the Northeast Region Decision Sciences Institute (NEDSI), 181-182.

Akdeniz, Y. (2016). Internette ırkçılık. İstanbul : İstanbul Bilgi Üniversitesi Yayınları 543.

Akın, A., Kaymak, A. vd. (2010). Yeni medyada nefret söylemi. (Haz. Tuğrul Çomu) İstanbul : Kalkedon Yayınları.

Altun, A. (2005). Gelişen teknolojiler ve yeni okuryazarlıklar. Ankara : Anı Yayıncılık

Aranda, J. F. (2007). Netiquette and online communication. Journal of Instruction Delivery Systems, 21(4), 11-14.

Arouri Y. M. ve Hamaidi D. A. (2017). Undergraduate students' perspectives of the extent of practicing netiquettes in a Jordanian Southern University. International Journal of Emerging Technologies in Learning (iJET) 12(3), 84-97. https://doi.org/10.3991/ijet.v12i03.6424

Binark, M. ve Bayraktutan, G. (2013). Ayın karanlık yüzü : yeni medya ve etik. İstanbul : Kalkedon Yayınları.

Brusco, J. M. (2011). Know your netiquette. AORN Journal, 94(3), 279-286. https://doi.org/10.1016/j.aorn.2011.07.003

Büyüköztürk, Ş. (2010). Sosyal Bilimler Için Veri Analizi El Kitabı. İstatistik, Araştırma Deseni SPSS Uygulamaları ve Yorum (11. baskı). Ankara: Pegem A yayıncılık.

Bynum, T. W. and Rogerson, S. (2006). Computer ethics and professional responsibility. Blackwell Publishing.

Çokluk, Ö., Şekercioğlu, G., \& Büyüköztürk, Ş. (2012). Sosyal bilimler için çok değiş̧kenli istatistik spss ve lısrel uygulamaları (2. baskı). Ankara: Pegem A yayıncılık. 
Deepa, S., \& Ghatak, S. (2013). Netiquette: Exploratory study of actual usage and agreed upon norms in India. Scholars world-irmjcr, 1(3), 129-136.

Farshad Nia, S., \& Marandi, S. (2014). Digital literacy and Netiquette: Awareness and perception in EFL learning context. In S. Jager, L. Bradley, E. J. Meima, \& S. Thouësny (Eds), CALL Design: Principles and Practice; Proceedings of the 2014 EUROCALL Conference, Groningen, The Netherlands (pp. 77-82). Dublin: Research-publishing.net. https://doi.org/10.14705/rpnet.2014.000198

Field, A. (2000). Discovering statistics using SPSS for windows. London: Sage Publications.

Flynn, N. (2009). Chapter 10: Netiquette Rules. In e-Policy Handbook: Rules \& Best Practices to Safely Manage Your Company's E-Mail, Blogs, Social Networking, \& Other Internet Communication

Gürcan, H.İ. (2011). İnternette medya okuryazarlı̆̆ 1 yaklaşımı XVI. Türkiyede Internet Konferansı 30 Kasım-2 Aralık 2011, Ege Üniversitesi, İzmir.

Heron, T.W., Cavico, F., Mujtaba, B.G. and Pellet, P.F. (2007), "Ethics and information technology professionals: an examination of gender, age, career stage, education level and ethics training variables", Proceedings of the EABR (Business) \& ETLC (Teaching) Conference, pp. 1-13.

Huck, S. W. (2000). Reading statistics and research. New York: Longman.

ISTE (2008). Standards for Teachers, 2008 - Permissions and Licensing - Permitted Educational Use. www.iste.org (Erişim Tarihi: 2017, 21 Mart)

ISTE (2009). Standards for Administrators, 2009 - Permissions and Licensing - Permitted Educational Use. www.iste.org (Erişim Tarihi: 2017, 21 Mart).

ISTE (2016). National Education Technology Standarts for Students. Permissions and Licensing - Permitted Educational Use. www.iste.org (Erişim Tarihi: 2017, 21 Mart).

Kalaycı, S. (2010). SPSS uygulamalı çok değişkenli istatistik teknikleri (5. Baskı). Ankara: Asil Yayın Dağıtım Ltd. Şti.

Khan M. (2007). Ethics in information systems, Long Beach Business Journal, August 28September 10.

Kocadağ, T.(2012) Öğretmen adaylarının dijital vatandaşlık düzeylerinin belirlenmesi. (Yayınlanmamış Yüksek Lisans Tezi). Karadeniz Teknik Üniversitesi Eğitim Bilimleri Enstitüsü, Trabzon.

Kuzu, A. (2009). Problems related to computer ethics: origins of the problems and suggested solutions. The Turkish Online Journal of Educational Technology - TOJET April 2009, 8(2), 91-110.

Namlu, A. G., \& Odabasi, F. (2007). Unethical computer using behavior scale: A study of reliability and validity on Turkish university students. Computers and Education, 48, 205215.

Preece, J. (2004). Etiquette online: from nice to necessary. Communications of the $A C M, 47(4)$, 56-61. https://doi.org/10.1145/975817.975845

TBD. (2011). Bilişim etiği. Kamu Bilgi İşlem Merkezleri Yöneticileri Birliği Kamu Bilişim Platformu XIII Bilişim Etiği 2. Çalışma Grubu Nihai Rapor, TBD/Kamu-B_B/2011-ÇG2. 
Uysal, Ö. (2006). Öğretmen adaylarının bilgisayar etiğine ilişkin görüşleri. (Yayınlanmamış Yüksek Lisans Tezi). Anadolu Üniversitesi Eğitim Bilimleri Enstitüsü, Eskişehir.

Uzun, R. (2011). Iletişim etiği: sorunlar ve sorumluluklar. 2. Baskı, Ankara : Dipnot Yayınları.

Scheuermann, L. \& Taylor, G. (1997). "Netiquette". Internet Research: Electronic Networking Applications and Policy, 7(4), 269-273. https://doi.org/10.1108/106622 49710187268

Şencan, H. (2005). Sosyal ve davranışsal ölçümlerde güvenirlilik ve geçerlilik. (Birinci Baskı). Ankara: Seçkin Yayınları.

Tavşancıl, E. (2002). Tutumların ölçülmesi ve spss ile veri analizi. (Birinci Baskı). Ankara: Nobel Yayın Dağıtım.

Timisi, N. (2003). Yeni iletişim teknolojileri ve demokrasi. (Birinci Baskı). Ankara: Dost Kitabevi Yayınları.

West, R. (2010). A student's guide to strengthening an online community. TechTrends: Linking Research \& Practice to Improve Learning, 54(5), 69-75. https://doi.org/10.1007/ s11528010-0439-7

Yarmohammadian, M. H., Iravani, H., \& Abzari, M. (2012). Information and communications technology, culture, and medical universities; organizational culture and Netiquette among academic staff. Journal of Education and Health Promotion, 1, 1-6. https://doi.org/10.4103/2277-9531.94414 


\section{SUMMARY}

It is a fact that the rapid development of internet and social networks today is causing significant changes on individuals and society and these changes will continue in the future. Beside its interactive nature, the most important feature of the Internet and social networks is that information and communication are indispensable resources for everyone. How to use internet and internet tools as a communication medium emerges as an important problem in terms of netiquette behaviors and etiquette rules. This study was conducted to determine the netiquette behaviors of preservice teachers while usıng internet and social networks. For this purpose, researchers tried to determine if teacher candidate's netiquette behaviors differed according to gender, age, department and class level and also whether the netiquette behaviors could be predicted based on internet use skill, duration and frequency.

The research was conducted using survey model. The sample of the research was composed of 315 preservice teachers in physics, Turkish Language and Literature, foreign language teacher certificate program, and Department of Computer and Instructional Technology Education (CEIT) program, of whom 113 were male and 202 were female. The age of the preservice teachers was between 18 and 50 years of age and the average age was 24.5. The data was gathered from the internet and social networks using preservice teachers with a scale developed by the researchers. The items in the scale consisted of 37 items with a five-point Likert-type choices. There were four sub-dimensions of the Netiquette behavior scale: E-mail Usage (15 items), Message Sharing (10 items), Content Generation (6 items) and Profile Usage ( 6 items). When the contribution of each factor to the explained variance was examined, $16.858 \%$ of the first factor, $11.925 \%$ of the second factor, $8.659 \%$ of the third factor and $6.864 \%$ of the fourth factor were explained. The contribution of these four factors to total variance was $44,306 \%$. The reliability coefficient calculated using the Cronbach Alpha scale was 0.865 . The reliability coefficients of the subscales were found to be $\alpha=0.897$ for the first factor, $\alpha=0.837$ for the second factor, $\alpha=0.730$ for the third factor and $\alpha=0.642$ for the fourth factor. During the study, the data collection process was explained to the participant using guidelines. The research was carried out on the basis of voluntary participation, and the questions from the participants during the research were answered. SPSS 17 package program was used for statistical analysis of the data. For the purpose of the study, total score of preservice teachers were calculated and tested by using one way variance analysis (ANOVA), which showed differences according to age, department and class levels. Whether or not the netiquette behaviors of preservice teachers differ according to the gender variable is tested using the unrelated tTest. Multilinear regression analysis was used to determine whether preservice teachers are predictors of net level of ethics and the level of internet use, year and duration.

Although the frequency of using the internet for female was higher than that for male participants, male students spend more time on the internet than female. According to internet usage, males sow themselves as expert level while females saw themselves in the middle. As age increased, the number of people who considered themselves as experts decreased. The duration of staying on the internet was between 2 and 4 hours. While there was no significant difference in netiquette behaviors of preservice teachers according to sex, there was a significant difference according to age, department and class levels. In general, netiquette behavior rates of female preservice teachers are higher than those of males. While e-mail usage and content production behaviors, which were sub-dimensions of netiquette behaviors, produced a meaningful difference in favor of female teacher candidates, it was seen that in message sharing behaviors, there was a difference in favor of male teacher candidates. There was no significant difference between the preservice teachers according to the sex in terms of profile use behaviors. According to the age variable, there is an increase in netiquette behavior as age increases. For e-mail usage and content production behaviors, 22-25 years and 26 years and over groups were significantly different from those in 21 years and under group. They showed similar characteristics 
in message sharing and profile use behaviors. According to the department variable, netiquette behaviors of the preservice teachers registered to foreign language program were higher than the candidates enrolled in Physics, CEIT and Turkish Language and Literature program. In the e-mail usage and content production behaviors, preservice teachers enrolled in a foreign language program showed a significant difference compared to the students enrolled in the CEIT and Physics programs, whereas CEIT student's message sharing behaviors showed a significant difference from the Turkish Language and Literature preservice teachers. In profile use behaviors, all prospective teachers show similar characteristics. The netiquette behavior scores also increased as the grade level of the preservice teachers increased. On the other hand, it has been seen that preservice teacher's internet usage skills were a significant predictor of their netiquette behavior, whereas the average number of years spent using the internet and using the internet did not seem to have any significant effect. As a result, it can be said that the netiquette behaviors of the preservice teachers differed in terms of age, department and class levels and did not change based on sex. 